\title{
Zinc Supplementation and Recurrent Diarrhea in Children in Kasihan Primary Health Care
}

\author{
Masta Hutasoit, Latifah Susilowati
}

Faculty Member, Nursing Study Program, University of Jenderal Achmad Yani Yogyakarta Jl. Brawijaya, Ringroad Barat, Ambarketawang, Gamping, Sleman Yogyakarta

Email : hutasoitmasta@gmail.com

\begin{abstract}
Abstrak
Tingginya angka kesakitan dan angka kematian balita karena diare masih menjadi focus pada kesehatan anak. Selain oralit, zinc merupakan suplemen yang diperlukan untuk mengatasi diare. Selama anak mengalami diare, tubuh akan kehilangan zinc, sehingga tambahan zinc dari luar sangat diperlukan untuk mempercepat proses penyembuhan diare. Zinc merupakan zat mikro yang penting pada pertumbuhan anak serta mampu mencegah diare 2-3 bulan setelah diare. Penelitian sebelumnya menunjukkan bahwa sebagian besar ibu-ibu tidak memberikan zinc pada anak diare (59,3\%), sehingga masih banyak kejadian diare berulang pada balita. Tujuan penelitian ini untuk mengetahui hubungan pemberian suplemen zinc dengan kejadian diare berulang.. Jenis penelitian ini adalah deskriptif korelasional dengan pendekatan retrospektif. Jumlah responden sebanyak 47 balita (059 bulan) yang mengalami diare yang dibawa ke Puskesmas dan mendapat terapi zinc. Teknik pengambilan sampel dilakukan dengan purposive sampling. Pengumpulan data dilakukan dengan kuesioner. Hasil dari uji Koefisien kontingensi diperoleh nilai p sebesar $0,013(P<0,05)$ sehingga diartikan terdapat hubungan yang bermakna secara statistic antara pemberian suplemen zinc dengan kejadian diare berulang pada balita diare. Keeratan hubungan antara kedua variable ditunjukkan dengan nilai koefisien korelasi sebesar 0,342 dengan keeratan hubungan sedang. Dapat disimpulkant ada hubungan pemberian suplemen zinc dengan kejadian diare berulang pada balita di Puskesmas Kasihan Bantul.
\end{abstract}

Kata Kunci: suplemen zinc, diare berulang, balita

Abstract
The high rate of infant morbidity and mortality due to diarrhea is still a focus on children's health. In addition to Oral Rehydration Salt (ORS), zinc is a supplement needed to treat diarrhea. As long as the child has diarrhea, the body will lose zinc, so that additional zinc is needed to accelerate the healing process of diarrhea. Zinc is an important micronutrient in the growth of children and is able to prevent diarrhea 2-3 months after diarrhea. The previous study showed that most mothers do not give zinc to diarrhea children (59.3\%), thus there are still many recurrent diarrhea in children. Objective of study to determine the relationship between zinc supplementation in children with diarrhea and the incidence of recurrent diarrhea. We used descriptive correlational with a retrospective approach. The number of respondents was 47 children under five years (0-59 months) with diarrhea who were taken to primary health care and received zinc therapy. The sampling technique was carried out by purposive sampling. Data collection was performed by filling out the questionnaire by home visit. The result of the contingency coefficient showed $p=$ $0.013(p<0.05)$ which means that there was a statistically significant relationship between zinc supplementation and the incidence of recurrent diarrhea. The closeness of the relationship between the two variables was indicated by the correlation coefficient 
value of 0.342 which was in a moderate relationship. There is a correlation between giving zinc supplementation to children with recurrent diarrhea in Primary Health Care

Keywords: zinc supplementation, recurrent diarrhea, children under five years

Article info:

Article submitted on December 24, 2019

Articles revised on February, 032020

Articles received on March 12, 2020

DOI: http://dx.doi.org/10.21927/jnki.2020.8(1).74-81

\section{INTRODUCTION}

Diarrhea is the second leading cause of mortality in children under five years after pneumonia. A global report shows that around $11 \%$ per year of children under five die of diarrhea (1). Incidence of diarrhea in Indonesia $10.25 \%$ and there are 8000 children die each year due to diarrhea (2). In 2014, there are increased cases by $1.8 \%$ from the previous year. This number is not an absolute number considering the many cases of diarrhea in children treated only by their own families at home (3).

The zinc supplementation has become the WHO standard in the effort to treat diarrhea in children. Zinc can reduce diarrhea by $25 \%$ and reduce the amount of fecal volume when diarrhea by $30 \%$. WHO recommends $20 \mathrm{mg}$ per day of zinc supplementation for 10-14 days. zinc can be given by mother, other caregivers, health workers including the nurses (4). While it has become a policy but there are still many mothers of children under five years who do not want to give zinc supplements for 10 days. They assume that when the diarrhea frequency has decreased or stopped, they no longer need to give zinc. Research in Banyumas by Sofiana (5) showed that $59.3 \%$ of mothers do not comply with zinc supplementation for their children. Non-compliance to give zinc supplementation to diarrhea children under five years is one of the causes of recurrent diarrhea. Recurrent diarrhea is diarrhea that occurs within 3 months after previously diarrhea was cured and has received zinc supplementation.

Nurses have an important role in the management of diarrhea. The nurse's role in management diarrhea is to provide education to mothers about providing zinc supplement for up to 10 days, even though diarrhea has stopped it still must be given. They should also explain the danger signs of diarrhea like dehydration and if happens should immediately brought to health services facility. In addition, nurses should provide education on how to give zinc supplementation and the dosage that must be given according to the age of the child (6).

The incidence of diarrhea in 2016 was still in the top 10 diseases in the primary health care area of Bantul District and the top 10 inpatient diseases at Panembahan Senopati District Hospital. Based on the background above, we interested in investigating the relationship between zinc supplementation and the incidence of recurrent diarrhea in infants in Kasihan Primary Health Care, Bantul. The formulation of the problem in this study is whether there is a relationship between zinc supplementation and the incidence of recurrent diarrhea in infants in the work area Kasihan primary health care, Bantul. The general objective of this research is to determine the relationship between zinc supplementation in children with diarrhea and the incidence of recurrent diarrhea at Kasihan Primary Health Care, Bantul. 


\section{MATERIALS AND METHODS}

This study was descriptive correlational with the retrospective approach. The location of the research was carried out in the Kasihan Primary Health Care, Bantul, Yogyakarta. The data collection was carried out in May to August 2018. The population in this study were all diarrhea children under five years who were treated at Kasihan Primary Health Care from December 2017 to June 2018 (aged 0-59 months). We used purposive sampling technique with the inclusion criteria such as children with diarrhea who received zinc supplementation, diarrhea without other comorbidities, living in the working area of Kasihan Primary Health Care, Bantul. The total samples in this study was 47 respondents. This study had been approved by the Health Research Ethics Committee of General Achmad Yani University, Yogyakarta, with the ethical approval number SKep/410/ STIKES/VIII/2018. Permission for the study was issued by the Local Regional Development Planning Agency of Bantul District and local government of Yogyakarta, Indonesia.The data was collected by a home visit to the respondents' house. We collected the data by asking parents based on the provided questionnaires. The questionnaires contained questions about the incidence of recurrent diarrhea for 2-3 months after previous diarrhea, as well as whether zinc supplements were given for 10 days or less. We conducted two data analysis in this study, namely univariate and bivariate analysis. Univariate analysis used the frequency and percentage of respondent's characteristics. We used bivariate analysis contingency coefficient analysis which to determine the relationship between zinc supplementation and the incidence of recurrent diarrhea. The normality test of the age of children were using the Shapiro Wilk test with resulting $p<0.05$, which means that the data was not normally distribute.

\section{RESULTS AND DISCUSSION}

\section{Univariate Analysis}

\section{Characteristics of Respondents (Children)}

Shows the characteristics of respondents. It showed that more than half of respondents were males (57.4\%). Based on age group, nearly half of respondents were between age 1-3 years $(42.6 \%)$. Nearly $60 \%$ of children were given zinc supplementation for diarrhea for 10 days. The incidence of recurrent diarrhea occured only about a quarter of total respondents $(23.4 \%)$.

Table 1. Distribution of Frequency of Respondents Based on Gender, Age, Giving Zinc Supplements and incidence of recurrent diarrhea ( $n=47$ respondents)

\begin{tabular}{lcc}
\hline $\begin{array}{c}\text { Characteristics of } \\
\text { Respondents }\end{array}$ & Frequency & $\begin{array}{c}\text { Percentage } \\
\text { (\%) }\end{array}$ \\
\hline Gender & 27 & 57.4 \\
Male & 20 & 42.6 \\
Female & & \\
Age Group & 11 & 23.4 \\
$\quad$ < 1 year & 20 & 42.6 \\
1-3 year & 16 & 34 \\
3-5 year & & \\
Giving Zinc & 19 & 40.4 \\
$\quad<10$ days & 28 & 59.6 \\
10 days & & \\
Recurrent diarrhea & 11 & 23.4 \\
$\quad$ Diarrhea & 36 & 76.6 \\
$\quad$ Not Diarrhea & 47 & 100 \\
\hline TOTAL & & \\
\hline
\end{tabular}

\section{Characteristics of Respondent (Parents)}

Table 2 shows the characteristics of the respondent's parents based on employment status and education. It showed that the majority

Table 2. Respondent Caracteristics of Parents by Job and Education( $n=47$ respondents)

\begin{tabular}{lcc}
\hline $\begin{array}{c}\text { Characteristics of } \\
\text { Respondents }\end{array}$ & Frequency & $\begin{array}{c}\text { Percentage } \\
\text { (\%) }\end{array}$ \\
\hline Job & 36 & 76.6 \\
$\quad$ Housewife & 11 & 23.4 \\
$\quad$ Employee / entrepreneur & & \\
Education & 13 & 27.7 \\
Basic (SD) & 25 & 53.2 \\
Middle (SMP) & 9 & 19.1 \\
High (SMA) & 47 & 100 \\
\hline TOTAL & & \\
\hline
\end{tabular}

Source: Primary Data (2018) 
of parents working as housewives (76.6\%). Whereas, sligthly half of parents only graduated from secondary education (53.2\%).

\section{Results of Tabulation of Zinc Supplement with Respondent Characteristics and parents of Respondents}

Table 3 shows the distribution of frequency of zinc supplementation based on respondents' characterisctics. It showed that $71.4 \%$ of male respondents was given zinc supplementation for 10 days. The age group that received the most zinc supplementation according to the recommended duration was at the age of 1-3 years $(46.42 \%)$.

\section{Results Tabulation of Recurrent Diarrhea Incidence with The Characteristics of Respondents}

The results of the analysis showed that the incidence of recurrent diarrhea was highest in males (63.63\%) (Table 4). Childrents of $1-3$ years age group did not experience recurrent diarrhea (46.42\%). Most of the respondents who parents were housewives were not experience recurrent diarrhea (76.59\%). In addition, more than half of the children who their parents graduated from secondary education did not experience recurrent diarrhea (55.56\%).

\section{Bivariate Analysis}

The results of bivariate analysis of the relationship between zinc supplementation and the incidence of recurrent diarrhea in infants using contingency coefficient analysis is show in Table 5, with p-value $=0.013(p<0.05)$. The closeness of the relationship showed moderate correlation indicated by the correlation coefficient ( $r$ ) 0.342 . This means that giving zinc supplements according to recommended duration (10 days) will reduce the incidence of recurrent diarrhea.

The results showed that more than half of respondents were already given zinc supplements in accordance with recommended duration (10 consecutive days) $(59.6 \%)$. This result is different from the previous research that the majority of respondents (74\%) were still not given zinc supplementation according to the recommendation (7). This might happen due to most of the respondents' parents have received health education by nurses of Kasihan Primary

Table 3. Distribution of Frequency of Zinc Supplement Providing Based on Characteristics of Respondents in Kasihan Primary Health Care Bantul

( $n=47$ respondents)

\begin{tabular}{|c|c|c|c|c|}
\hline \multirow{2}{*}{$\begin{array}{l}\text { Characteristics of } \\
\text { Respondents }\end{array}$} & \multicolumn{2}{|c|}{ Giving of Zinc Supplement } & \multirow{2}{*}{$\mathbf{N}$} & \multirow{2}{*}{$\%$} \\
\hline & $<10$ day & 10 day & & \\
\hline \multicolumn{5}{|l|}{ Gender } \\
\hline Male & $7(36.84 \%)$ & $20(71.4 \%)$ & 27 & 57.44 \\
\hline Female & $12(63.15 \%)$ & $8(28.57 \%)$ & 20 & 42.55 \\
\hline \multicolumn{5}{|l|}{ Age Group } \\
\hline$<1$ year & $5(26.31 \%)$ & $6(21.42 \%)$ & 11 & 23.40 \\
\hline 1-3 year & $7(36.84 \%)$ & $13(46.42 \%)$ & 20 & 42.6 \\
\hline 3-5 year & $7(36.84 \%)$ & $9(32.14 \%)$ & 16 & 34 \\
\hline \multicolumn{5}{|l|}{ Parents' job } \\
\hline Housewife & 12(63.15) & $24(85.71)$ & 36 & 76.59 \\
\hline Employee / entrepreneur & $7(36.84)$ & $4(14.28)$ & 11 & 23.4 \\
\hline \multicolumn{5}{|l|}{ Parent education } \\
\hline Basic & $8(42.1)$ & $5(17.85)$ & 13 & 27.65 \\
\hline Middle & $6(31.6)$ & $19(67.85)$ & 25 & 53.19 \\
\hline High & $5(26.3)$ & $4(14.28)$ & 9 & 32.14 \\
\hline Total & & & 47 & 100 \\
\hline
\end{tabular}

Source: Primary Data (2018) 
Table 4. Distribution of Frequency of Recurrent Diarrhea Incident Based on Characteristics of Respondents in Kasihan Primary Health Care Bantul ( $n=47$ respondents)

\begin{tabular}{|c|c|c|c|c|}
\hline \multirow{2}{*}{ Characteristics of Respondents } & \multicolumn{2}{|c|}{ Recurrent Diarrhea } & \multirow{2}{*}{$\mathbf{N}$} & \multirow{2}{*}{$\%$} \\
\hline & Diarrhea & Not Diarrhea & & \\
\hline \multicolumn{5}{|l|}{ Gender } \\
\hline Male & $7(63.63 \%)$ & $20(55.56 \%)$ & 27 & 57.44 \\
\hline Female & $4(36.36 \%)$ & $16(44.44 \%)$ & 20 & 42.55 \\
\hline \multicolumn{5}{|l|}{ Age Group } \\
\hline$<1$ year & $0(0 \%)$ & $11(14.28 \%)$ & 11 & 23.40 \\
\hline 1-3 year & $6(35 \%)$ & $14(46.42 \%)$ & 20 & 42.55 \\
\hline 3-5 year & $5(40 \%)$ & $11(32.14 \%)$ & 16 & 34 \\
\hline \multicolumn{5}{|l|}{ Parents' job } \\
\hline Housewife & $7(63.63 \%)$ & $29(80.5 \%)$ & 36 & 76.59 \\
\hline Employee / entrepreneur & $4(36.36 \%)$ & $7(19.4 \%)$ & 11 & 23.4 \\
\hline \multicolumn{5}{|l|}{ Parent education } \\
\hline Basic & $4(36.36 \%)$ & $9(25 \%)$ & 13 & 27.65 \\
\hline Middle & $5(45.45 \%)$ & $20(55.56)$ & 25 & 53.19 \\
\hline High & $2(18.18)$ & $7(19.4 \%)$ & 9 & 19.14 \\
\hline Total & & & 47 & 100 \\
\hline
\end{tabular}

Source: Primary Data (2018)

Table 5 Relation of zinc supplementation with recurrent diarrhea in children under five in Kasihan Primary Health Care Bantul ( $n=47$ respondent)

\begin{tabular}{|c|c|c|c|c|c|}
\hline \multirow{2}{*}{ Zinc supplements } & \multicolumn{2}{|c|}{ The incidence of recurrent diarrhea } & \multirow[b]{2}{*}{$\mathbf{n}$} & \multirow[b]{2}{*}{$\mathbf{p}$} & \multirow{2}{*}{$\begin{array}{c}\text { Correlation } \\
\text { coefficient }(r)\end{array}$} \\
\hline & Diarrhea & Not diarrhea & & & \\
\hline$<10$ day & $8(72.72 \%)$ & $11(30.55 \%)$ & 19 & & \\
\hline 10 day & $3(27.27 \%)$ & $25(69.44 \%)$ & 28 & 0.013 & 0.342 \\
\hline Total & 11 & 36 & & & \\
\hline
\end{tabular}

Source: Primary Data (2018)

Health Care, Bantul, that zinc supplementation given to children under five years with diarrhea should be given for 10 days according to the dose given even though the children have recovered from diarrhea or getting better (4). However, the counseling about zinc supplementation for diarrhea by each nurse needs to be improved. It is because $40.4 \%$ of parents were still giving the zinc supplementation less than 10 days.

We completed questions of the questionnaire if the mother answered that she did not give zinc supplements for 10 days, thus the mothers need to answer the reasons of doing so. It resulted that the reason mothers did not give zinc supplements for 10 days was due to children diarrhea had stopped (52.63\%), children experienced vomiting after taking zinc supplements (26.3\%) and mothers forgot to give zinc supplements and children refused to take zinc supplements (21.05\%). Based on previous study, the reason mothers did not complete with zinc supplements for 10 days because children have recovered from diarrhea (8). The reason of mothers who stopped giving zinc to children before 10 days was due to its side effect which causes vomiting. The risk of vomiting after consume zinc supplementation increased in children older than 6 months (9). High doses of zinc lead to epigastric pain and lethargy and its metallic taste also can induce vomiting (10). The Indonesia Ministry of Health recommends giving zinc to children who experience diarrhea for ages less than 6 months at $10 \mathrm{mg}$ and more than 6 months at $20 \mathrm{mg}$ with a duration for 10 days (11). 
Diarrhea increased zin excretion from body through feces. This condition leads to the level of zinc in the tissue lower (12). Zinc is one of the important micronutrients in the body. Zinc can inhibit INOS (Inducible Nitric Oxide Synthase) enzyme, where the excretion of this enzyme increases during diarrhea and results in intestinal epithelial hypersecretion. Zinc also plays a role in epithelialization of the intestinal wall where it is morphologically damaged and loss its function during the diarrhea (19). Zinc plays a role in immunity development, stains, infection, vision and metabolism in the body. Zinc needs is vary greatly depending on physiological conditions, such as the amount of zinc that must be absorbed to replace endogenous expenditure, tissue formation, growth and secretion through the intestine. So that the physiological needs of zinc depend on one's age and physiological status. Zinc needs is also affected by pathological conditions. When a person experiences infection, trauma, and absorption disorders, zinc needs will also increase (13).

The results of this study indicated the incidence of recurrent diarrhea was only a small portion $(23.4 \%)$, while respondents who did not experience diarrhea were $76.6 \%$. Previous research reported that most children underwent recurrent diarrhea (72\%) and followed by a large portion of incorrect zinc suppelementation (74\%) . This is consistent with previous studies which concluded that children with diarrhea given zinc supplementation have protection against recurrent diarrhea (14).

Recurrent diarrhea is a persistent infection that can be caused by incomplete healing, infection by other pathogens, or food intolerance due to the intestinal function that has not returned completely. Children who have a history of recurrent diarrhea are associated with diarrhea (15). The subjects with a history of recurrent diarrhea had a 3.4 times risk for diarrhea to continue. The cause of recurrent diarrhea can be caused by damage to the intestinal mucosa due to imperfect infections, food allergies or disaccharide deficiency.

The results of the analysis of the relationship between zinc supplementation and the incidence of recurrent diarrhea in children under five using the contingency coefficient analysis was resulted a $p$-value $=0.013(p<0.05)$ with the closeness of the relationship indicated by correlation coefficient ( $r$ ) was moderate (0.342). This means that giving zinc supplements according to the recommended duration (10 days) will reduce the incidence of recurrent diarrhea.

The results of this study are also in line with previous research who reported that there was a relationship between zinc administration and the incidence of recurrent diarrhea in children under five (7). Zinc can provide a protective effect on diarrhea in children for 3 months with a reduction in the incidence of diarrhea by $13 \%$ and the rate of morbidity due to diarrhea decreased by $15 \%$ (16). Zinc supplementation has been shown to reduce the duration and severity of diarrhea and to prevent subsequent episodes (4).

One of the factors that influence zinc levels in the body is the condition of the body that experiences acute infection and inflammation. Infection and inflammation cause low levels of zinc in the body serum because zinc is channeled back from the serum to the liver (13). Zinc serves to accelerate regeneration and improve the function of the intestine, so that it will affect the formation of disaccharidease enzymes such as lactase, sucrose, and maltase, besides zinc also affects sodium and glucose transport. In addition, zinc also functions to enhance the body's immune response which leads to the clearance of pathogens from the intestine and mediators that are potential in the body's immunity to infection so that zinc can help the healing process of diarrhea (17). The process of healing diarrhea includes a decrease in diarrhea episodes, fecal excretion, the frequency of 
bowel movements, and length of treatment in the hospital (18)but the impact of zinc treatment among children under five has not been well documented by previously published systematic reviews on the topic. We therefore conducted a systematic literature review, which included an exhaustive search of the Chinese literature, in an effort to update previously published estimates of the effect of therapeutic zinc. We conducted systematic literature searches in various databases, including the China National Knowledge Infrastructure (CNKI. Increased body immunity due to zinc supplement can reduce the risk of subsequent recurrent diarrhea. The condition of patients with zinc deficiency tends to experience more severe diarrhea (15).

The strength of this study was that the investigators conducted a home visit so that it could conducted direct interviews and in more detail about the reason parents did not give zinc supplements for 10 days. In addition, we asked parents whether they had received an explanation from the nurse at the Primary Health Care that they had to give zinc supplementation for 10 days. The limitation of this study was that we do not directly observe the mother's compliance in giving zinc supplementation.

\section{CONCLUSIONS AND RECOMMENDATION}

In conclusion, there is a correlation between zinc supplementation and the incidence of recurrent diarrhea in Kasihan Primary Health Care, Bantul. Most children are given zinc supplementation in accordance with the recommendation (for 10 days) (59.6\%). The incidence of recurrent diarrhea in infants after being given zinc during previous diarrhea is $76.6 \%$, no recurrent diarrhea occurs. There is a relationship between zinc supplementation and the incidence of recurrent diarrhea in Kasihan Primary Health Care, Bantul and the closeness or the relationship between zinc supplementation and recurrent diarrhea is 0.342 .
Parents have to give zinc supplementation to their children under five years when diarrhea in accordance with the specified dose and time (10 days) because zinc supplementation is known to prevent recurrent diarrhea for the 2-3 months later. Primary Health Care health worker especially nurse, have to give more attention to health counseling about the benefits of zinc on diarrhea in children under five years to reduce the incidence of recurrent diarrhea, thus more mothers consistently give zinc to their children under five years with diarrhea according to the recommendation (10 days). Health education about giving zinc to children under five years who experience diarrhea is not only through oral communication from nurses but can be added to other media such as leaflets and banners. This study is expected to be used as basic data or references for those who want to conduct similar research elsewhere, or even as a basis for conducting research with other factors.

\section{REFERENCES}

1. WHO/UNICEF. Ending Preventable Child Deaths from Pneumonia and Diarrhoea by 2025. The Integrated Global Action Plan for Pneumonia and Diarrhea (GAPPD) [Internet]. 2013. Available from: http://www. unicef.org/media/files/Final_GAPPD_main_ Report-_EN-8_April_2013.pdf

2. Health Ministry of Indonesia. Riset Kesehatan Dasar (Basic Health Research). Jakarta: Health Ministry of Indonesia; 2013.

3. Yogyakarta Health Service. Profil Kesehatan D.I.Yogyakarta Tahun 2014. (Health Profile of Yogyakarta in 2014). Yogyakarta: Yogyakarta Health Service; 2015.

4. WHO. Zinc supplementation in the management of diarrhoea [Internet]. 2017. Available from: http://www.who.int/elena/ titles/zinc_diarrhoea/en/

5. Sofiana D. Gambaran tingkat Kepatuhan Ibu Dalam Pemberian Tablet Zinc Pada Balita Diare di Puskesmas Banyumas. 2015; 
6. Health Ministry of Indonesia. Integrated Management of Children Ilnesses. Jakarta: Health Ministry of Indonesia; 2015.

7. Hastuti D. Hubungan pemberian zinc dengan kejadian diare berulang pada balita di wilayah kerja Puskesmas Kedungmundu Kota Semarang. (The relationship between zinc with recurrent diarrhea in children at Kedungmundu Primary Health Care, Semarang. Unpublish. 2017;

8. Nisaa M. Hubungan Pengetahuan dengan Kepatuhan Ibu dalam Pemberian Zinc Pada Balita Penderita Diare di Puskesmas Helvatia Medan. (The correlation Knowledge and Maternal Compliance in Giving Zinc to children under five years old with at Hevatia Primary Health Care). 2017; Available from: http://repositori.usu.ac.id/ handle/123456789/1556

9. Lazzerini $\mathrm{M}$, Wanzira $\mathrm{H}$. Oral zinc for treating diarrhoea in children Cochrane Database of Systematic Reviews. 2016;(12).

10. Somji SS, Dhingra $P$, Dhingra $U$, Dutta A, Devi P, Kumar J, et al. Effect of dose reduction of supplemental zinc for childhood diarrhoea: study protocol for a doublemasked, randomised controlled trial in India and Tanzania. BMJ Paediatrics Open. 2019;(3)e000460.1-9.

11. Health Ministry of Indonesia. Buku Saku Lintas Diare. (Diarrhea Pocket Book). Jakarta: Directorate General of Disease Control and Environmental Health; 2011.

12. Alam K, Poudel A, Palaian S, Koirala B, Shankar PR. Role of Zinc in childhood diarrhea management: a case of Nepal. Journal of Pharmacy Practice and Community Medicine. 2017;3(1):34-36.

13. Adriani, M., Wirjatmadi B. Gizi dan Kesehatan Balita Peranan Mikro Zinc pada Pertumbuhan Balita Edisi Pertama. (Nutrition and Health of Toddler: Role of Micro Zinc in Toddler Growth). 1st ed. Jakarta: Kencana; 2014.

14. Purnamasari, H., Santosa, B., Puruhita N. Pengaruh suplementasi seng dan probiotik terhadap kejadian diare berulang. Sari Pediatri. 2011;13(2):96-104.

15. Marlia, DL., Dwipoerwantoro, PG., Advani N. Defisiensi zinc sebagai salah satu faktor risiko diare akut menjadi diare melanjut (Zinc deficiency is one of the risk factor acute diarrhea to be chronic diarrhea). Sari Pediatri. 2015;16(5):299-306.

16. Yakoob MY et al. Preventive zinc supplementation in developing countries: impact on mortality and morbidity due to diarrhea, pneumonia and malaria. BMC Public Health. 2011;11(Suppl 3):1-10.

17. Latif $\mathrm{H}$. Terapi suplementasi zink dan probiotik pada pasien diare (Zinc Supplementation and probiotic therapy in patient with diarrhea). J Agromed Unila. 2014;2(4):440-5.

18. Lamberti, LM., Walker, CLF., Chan, KY., Jian, WY., Black RE. Oral Zinc Supplementation for the Treatment of Acute Diarrhea in Children: A Systematic Review and MetaAnalysis. Nutrients. 2013;4715-40.

19. Health Ministry of Indonesia. Situasi Diare di Indonesia. (Diarrhea Situation in Indonesia). Jakarta: Health Ministry of Indonesia;2011. 